\title{
Infographic. Graduated return to play guidance following COVID-19 infection
}

\author{
Niall Elliott (D) , ${ }^{1,2}$ Rhodri Martin, ${ }^{3,4}$ Neil Heron, ${ }^{5,6}$ Jonathan Elliott (D) , ${ }^{7}$ Dan Grimstead, ${ }^{3}$ Anita Biswas ${ }^{8}$
}

\section{COVID-19 AND SPORT}

With risk of cardiological, renal, respiratory and haematological complications, ${ }^{1-5}$ it is best practice to follow steady resumption of training, paying attention to physical and psychological factors after COVID-19 infection.

\section{SCOPE OF THIS INFOGRAPHIC}

This guidance takes into account public health guidelines in the UK (although we hope its content is relevant more widely) and available expert opinion at time of publication and is for use by healthcare practitioners. It is applicable to performance athletes who have had mild to moderate illness. Those requiring hospital admission merit further assessment.

\section{COVID-19 CLINICAL GUIDANCE}

If an athlete develops an illness with symptoms of COVID-19, they should follow national guidance, speak to their sports medicine doctor, and undertake

\section{COVID-19 GRADUATED RETURN TO PLAY FOR PERFORMANCE ATHLETES: GUIDANCE FOR MEDICAL PROFESSIONALS}

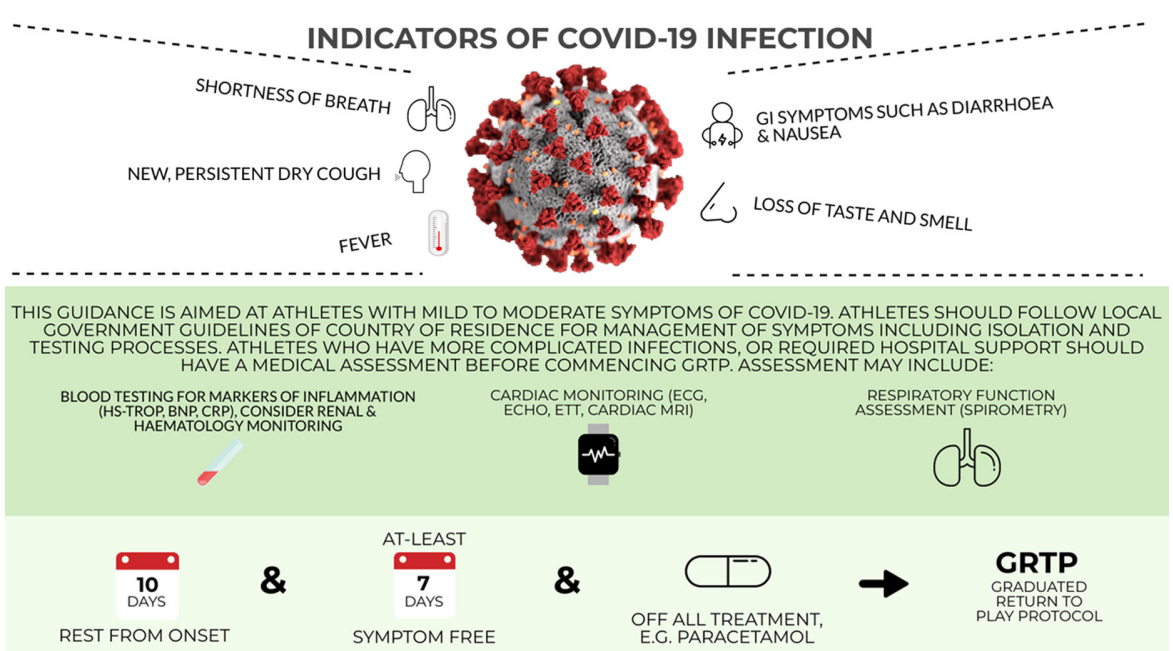

GRADUATED RETURN TO PLAY PROTOCOL UUNDER MEDICAL SUUPERVIISION

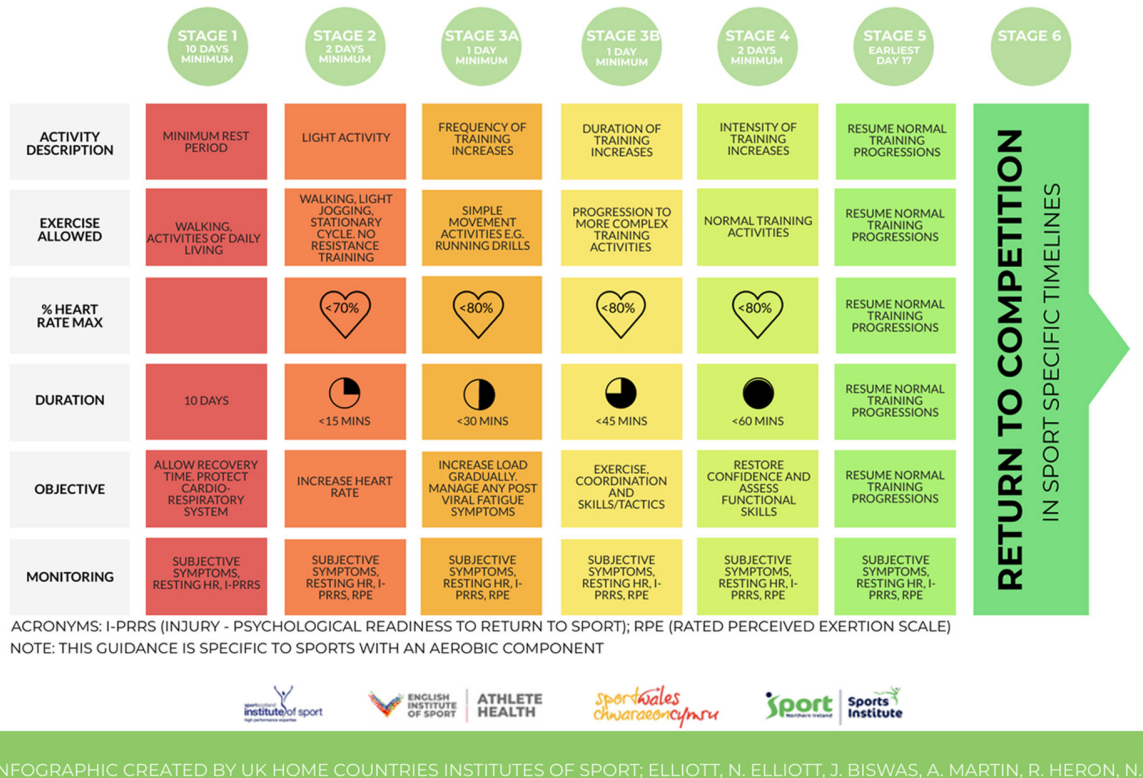

appropriate quarantine, testing and tracing.

They should maintain good hydration, a balanced diet and, if symptoms worsen or persist beyond 7 days, seek further medical review.

Quarantine when living with others includes practical aspects such as isolating within rooms not accessed by other persons, maintaining supplies of food and water, use of a different toilet and washing dirty linen and clothes regularly.

\section{GRADUATED RETURN TO PLAY (GRTP) PROTOCOL}

A GRTP is a progressive programme that introduces physical activity and sport in a stepwise fashion.

Key considerations

- Before considering GRTP, the athlete must be able to complete activities of daily living and walk $500 \mathrm{~m}$ on the flat without excessive fatigue or breathlessness.

- They should have at least 10 days' rest and be 7 days symptom-free before starting.

- Less aerobically intense sports like golf may progress quicker. Experience suggests that some athletes take over 3 weeks to recover.

Some monitoring may add value, which could includes

- Resting heart rate.

- Rated perceived exertion.

- Sleep, stress, fatigue and muscle soreness.

- Injury-Psychological Readiness to Return to Sport.

If any symptoms occur (including excessive fatigue) while going through GRTP, the athlete must return to the previous stage and progress again after a minimum of 24 hours' period of rest without symptoms.

\section{ATHLETES WITH COMORBIDITIES}

Athletes diagnosed with COVID-19 and who have medical conditions such as diabetes, cardiovascular disease or renal disease should have a medical assessment before commencing GRTP.

\section{FURTHER ASSESSMENTS}

Athletes who have a complicated or prolonged COVID-19 illness may need further investigations, including 
- Blood testing for markers of inflammation (high sensitivity-Troponin, Brain Natriuretic Peptide and C reactive protein). ${ }^{34}$

- Cardiac monitoring (12-lead ECG, echocardiogram, exercise tolerance test and cardiac MRI). ${ }^{34}$

- Respiratory function assessment (spirometry).

- Renal and haematological monitoring. ${ }^{1}$ Sports Medicine, Sportscotland Institute of Sport, Stirling, UK

${ }^{2}$ Sports Medicine, NHS Tayside, Dundee, UK

${ }^{3}$ Sports Medicine, Sport Wales, Cardiff, UK

${ }^{4}$ Sport and Exercise Medicine, Cwm Taf Morgannwg University Health Board, Abercynon, UK

${ }^{5}$ Sports Medicine, Sports Institute Northern Ireland, Newtownabbey, UK

${ }^{6}$ Queen's University Belfast Centre for Public Health, Belfast, UK

${ }^{7}$ Faculty of Medicine Health and Life Sciences, Queen's University Belfast, Belfast, UK

${ }^{8}$ Sports Medicine, English Institute of Sport, Manchester, UK

Correspondence to Dr Niall Elliott, Sports Medicine, Sport Scotland Institute of Sport, Stirling FK9 5PH, UK ; niall.elliott@sisport.com

Twitter Niall Elliott @dundeesportsmed and Jonathan Elliott @jelliott1989

Acknowledgements $\mathrm{CMcC}$ : Sportscotland Institute of Sport; CR: English Institute of Sport.
Contributors $\mathrm{RM}, \mathrm{NH}, \mathrm{JE}, \mathrm{AB}$ and $\mathrm{DG}$ provided material and edits to the documents from the outset of the guidance creation. Lead authorship by NE.

Funding The authors have not declared a specific grant for this research from any funding agency in the public, commercial or not-for-profit sectors.

Competing interests $N E, R M, N H, D G$ and $A B$ received remuneration from sporting organisations as per author affiliations.

Patient consent for publication Not required.

Provenance and peer review Not commissioned; externally peer reviewed.

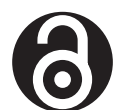

\section{OPEN ACCESS}

Open access This is an open access article distributed in accordance with the Creative Commons Attribution Non Commercial (CC BY-NC 4.0) license, which permits others to distribute, remix, adapt, build upon this work non-commercially, and license their derivative works on different terms, provided the original work is properly cited, appropriate credit is given, any changes made indicated, and the use is non-commercial. See: http:// creativecommons.org/licenses/by-nc/4.0/.

(c) Author(s) (or their employer(s)) 2020. Re-use permitted under CC BY-NC. No commercial re-use. See rights and permissions. Published by BMJ.

A Check for updates
To cite Elliott N, Martin R, Heron N, et al. Br J Sports Med 2020:54:1174-1175.

Accepted 31 May 2020

Published Online First 22 June 2020

Br J Sports Med 2020:54:1174-1175. doi:10.1136/bjsports-2020-102637

\section{ORCID iDs}

Niall Elliott http://orcid.org/0000-0002-5394-975X Jonathan Elliott http://orcid.org/0000-0002-1087-9720

\section{REFERENCES}

1 Condliffe Ret al. British thoracic Society guidance on venous thromboembolic disease in patients with COVID-19 British thoracic Society pulmonary vascular specialist Advisory group 2020.

2 Perico L, Benigni A, Remuzzi G. Should COVID-19 concern nephrologists? why and to what extent? the emerging impasse of angiotensin blockade. Nephron 2020;144:213-21.

3 Bhatia RT, Marwaha S, Malhotra A, et al. Exercise in the Severe Acute Respiratory Syndrome Coronavirus-2 (SARS-CoV-2) era: A Question and Answer session with the experts Endorsed by the section of Sports Cardiology \& Exercise of the European Association of Preventive Cardiology (EAPC). Eur J Prev Cardiol. In Press 2020:204748732093059.

4 Baggish A, Drezner J. The resurgence of sport in the wake of COVID-19: cardiac considerations in competitive athletes. BJSM. Available: https://blogs. bmj.com/bjsm/2020/04/24/the-resurgence-of-sportin-the-wake-of-covid-19-cardiac-considerations-incompetitive-athletes/

5 Hull J, Loosemore M, Schwellnus M. Respiratory health in athletes; facing the COVID-19 challenge. The Lancet. 